\title{
Sedimentology, stratigraphy, and glacier dynamics, western Scottish Highlands.
}

\author{
Nicholas R. Golledge \\ British Geological Survey, Murchison House, West Mains Road, Edinburgh, EH9 3LA* and \\ School of Geosciences, University of Edinburgh, West Mains Road, Edinburgh, EH9 3JW, \\ email n.golledge@bgs.ac.uk, phone +44 1316671000. \\ (*Address for correspondence)
}


Abstract

Glacial sediments of the western Scottish Highlands are comprehensively described and characterized here for the first time, enabling the first glacial stratigraphy for the area to be proposed. This classification is based on the results of extensive geological mapping and field investigation of sedimentary sequences and their structures, X-Ray Diffraction and Particle Size Distribution analyses, and comparison with deposits formed in contemporary glaciated environments. These new data are subsequently appraised in terms of their implications for late Pleistocene glacier evolution and dynamics. Together, the data suggest that much of the landscape is palimpsest, and can be attributed to the Weichselian (Late Devensian) glaciation. Subsequent glacier advance during the Younger Dryas did little to modify the area, suggesting that ice flow was dominated by sliding on a meltwater-lubricated rigid bed, with deformation of basal sediments playing a more limited role. Final deglaciation was marked by a significant increase in basal meltwater flux, reflecting the warming climate and increasing precipitation. These new palaeoglaciological and palaeoenvironmental insights advance our understanding of former glacier dynamics in the western Scottish Highlands, improve our knowledge of Pleistocene landscape evolution of this area, and enable comparisons to be made with sedimentary sequences elsewhere.

KEYWORDS: Late Weichselian; Younger Dryas; British Ice Sheet; stratigraphy; glacier dynamics; palaeoglaciology; Scotland. 


\section{Background}

The growth and decay of ice caps and ice sheets is intimately related to global climate change, hydrological storage, land-ocean sediment flux and long-term landscape evolution (Alley \& MacAyeal, 1994; Krüger, 1996; Hodgkins, 1997; Alley, 2000; Jansson et al., 2003; Barnard et al., 2006). The study of former ice-mass behaviour may therefore be useful in understanding how these Earth-systems operated in the geological past. Perhaps the most direct evidence available for the study of former glacier dynamics is the sedimentary record left by the ice. Indeed, geological and geomorphological mapping of deglaciated terrains is often used to determine the size and extent, (i.e. the geometry), of both ancient ice masses as well as those that were formerly more extensive (e.g. Sugden, 1977; Thorp, 1986; Van Tatenhove et al., 1996; Clark, 1997; Anderson et al., 2002; Evans et al., 2005). In Britain this approach has been employed since the earliest recognition of glacial features (Agassiz, 1841; Geikie, 1863; Hinxman et al., 1923; Charlesworth, 1955) and has enabled significant advances to be made in our understanding of Earth-system processes. More recent developments, in both geological and glaciological sciences, have allowed far more detailed interpretations to be made now than ever before, particularly when founded on empirical data from field mapping (Benn, 1994; Mitchell, 1994; Merritt et al., 1995; Lowe \& Anderson, 2003; Clark et al., 2004; Glasser \& Bennett, 2004). Additionally, fieldbased reconstructions are often used to inform, test or constrain numerical models (e.g. Van Tatenhove et al., 1996; Jones, 1998; Golledge \& Hubbard, 2005; Hubbard et al., 2005).

Oxygen isotope data obtained from Greenland ice cores show that the climate of the northern hemisphere oscillated between cold and warm phases throughout the late Pleistocene, giving rise to particularly long-lasting cold periods from c. 70-57 ka BP (Oxygen Isotope Stage 4) and from c. 25-15 ka BP (Oxygen Isotope Stage 2) (Dansgaard et al., 1993). Interstadials punctuated these colder spells, most notably prior to c. $90 \mathrm{ka}$ BP and from c. 35-28 ka BP, during which temperatures ameliorated slightly, but were still sufficiently low that glaciers would have survived in the Scottish Highlands (Clapperton, 1997). Palaeoclimatic data based on coleopteran and chironomid data from four sites in Britain indicate that even during the Windermere Interstadial, (c. 15-13 ka BP), the climate affecting Scotland was warm for only a short time before renewed cooling and instability led to the onset of the Younger Dryas stadial (Mayle et al., 1999). This period of renewed global cooling was characterized in Scotland by an abrupt c. 8 $10^{\circ} \mathrm{C}$ drop in mean annual temperature at its onset, a subsequent decline in precipitation due to 
sea ice formation during the Stadial, and final rapid warming that terminated the glacial readvance (Benn et al., 1992; Clapperton, 1997; Hubbard, 1999; Isarin \& Renssen, 1999).

This study reports geological and geomorphological field data gathered by the British Geological Survey over the period 2003 - 2006, during the resurvey of part of the western Scottish Highlands (Fig. 1), together with the results of sedimentological analyses and palaeoglaciological reconstructions. Facies genesis is established by comparison of sedimentary characteristics with contemporary analogues in Iceland and Svalbard and with descriptions of similar deposits in the literature. Together, these data allow a new stratigraphy to be presented and conclusions to be drawn with respect to the former dynamics of the ice masses that overwhelmed this part of the western Scottish Highlands during both the Main Late Devensian (Late Weichselian, c. 25 - 15 ka BP) and the Younger Dryas (12.7-11.3 ka BP).

\section{Field area}

The research is focussed on a large area $\left(960 \mathrm{~km}^{2}\right)$ of the western Scottish Highlands to the south of Rannoch Moor and north of Loch Lomond (Figs. 1 \& 2 A). The study area is one of steepsided mountains and intervening ' $U$ '-shaped valleys (glens), with many mountain tops covered in regolith derived from metasedimentary bedrock. Where the regolith mantle has been affected by frost-heave, saturation by rainfall, and gravity, solifluction terracettes have resulted. Exposed bedrock is particularly common, with talus aprons or cones developed below most crags. Some of the valleys host a covering of till along their flanks and floors, which varies in thickness from 1 $30 \mathrm{~m}$. In many places the till is overlain by morainic deposits of poorly-sorted sand, gravel and diamicton, which often form elongate boulder-strewn ridges. Glaciofluvial deposits are not extensive, and where present are mainly confined to large fans and sparse ice-contact features. The floors of many valleys reflect fluvial activity since deglaciation, and exhibit rock-cut channels, thin bouldery alluvium, or large and extensive terraces of sand and gravel. Peat overlies much of the ground at both high and low levels, and although generally thin, attains thicknesses of up to $3 \mathrm{~m}$ in some places.

\section{[FIGURE 1 HERE]}

\section{Previous research}

Early mapping by the Geological Survey $(1890$ - 1920) focussed on the bedrock geology of the area, with limited description of the abundant glacial deposits, their inter-relationships, and their association with the wide variety of landforms present. Reconstruction of the glacial history was attempted for adjoining areas by Hinxman et al. (1923), who recognised that much of the area had 
been overwhelmed by ice from Rannoch Moor during the Last Glacial Maximum (LGM). Charlesworth (1955) described the moraines and ice-marginal features of much of the Scottish Highlands; in the field area described here he associated these features with the decay of glaciers after his 'Highland Readvance'. Sissons (1965) later proposed that the 'hummocky moraine' seen in the area resulted from in situ stagnation of glaciers at the end of a renewed phase of glaciation after the Main Late Devensian ice sheet had disappeared. Subsequent mapping has been limited to studies that cover smaller parts of the area (Thompson, 1972; Horsfield, 1983; Thorp, 1984, 1986, 1987, 1991b), and which mainly describe geomorphological rather than sedimentological features. Nonetheless, these studies have greatly improved our understanding of the former Younger Dryas ice mass that affected the area most recently. Whilst Thompson (1972) favoured a valley-glacier type reconstruction, Horsfield (1983) concluded that the area had been glaciated by an invasive ice cap centred on the Etive and Nevis mountains to the north-west. Thorp (1984, 1986) based his reconstruction on periglacial 'trimlines', and deduced that the ice cap on Rannoch Moor was relatively thin, restricted in extent, and fed outlet glaciers that together formed a mountain icefield. Recently, Golledge \& Hubbard (2005) reassessed the area and found field evidence suggesting a thicker Younger Dryas ice cap than proposed by Thorp. The empirical reconstruction based on this data finds good agreement with the numerical model of Hubbard (1999).

Given the differing interpretations and the lingering uncertainty surrounding the style and impact of Younger Dryas glaciation in the western Scottish Highlands, the intention here is to set out a new stratigraphical framework based on sedimentological classification of the glacial deposits of the study area, and to use this to inform interpretations of former local and regional glacier dynamics.

\section{Methods}

\section{Data capture}

Geomorphological features and interpreted geological boundaries were added to 1:10 000 or 1:25 000 scale topographic base maps from the interpretation of 1:24 000 scale monochrome aerial photographs, high-resolution digital terrain models (DTMs), and where applicable, Thematic Mapper satellite imagery. This was achieved either digitally in an onscreen GIS environment, or in a more traditional manner using paper map bases. These interpretations were subsequently field-checked by detailed walk-over survey in which lines were modified as appropriate. 
Sedimentological data was added to the map based on the availability and accessibility of natural sections. The distribution of 53 logged sections is shown on Fig. 2 A, although the many hundreds of minor exposures noted on field maps that informed the geological interpretation are, for clarity, not shown. For deposits with consistent matrix colour a Munsell Soil Color chart was used (Table 1).

[FIGURE 2 HERE]

\section{PSD and XRD analysis}

Samples were collected from four of the key facies described below for X-Ray Diffraction (XRD) and Particle Size Distribution (PSD) analysis. Only deposits possessing a relatively homogeous matrix were deemed meaningful for analysis. Samples for XRD analysis were freeze-dried prior to grinding in a tungsten-carbide gyromill to produce a fine powder. Discs were prepared of each powdered sample using metal mounts, and were analysed using a Philips PW 1800 X-Ray Diffractometer to produce diffractograms. Systematic peak-matching against standard spectra enabled dominant compounds to be identified. Samples for PSD were taken from wet sediment, agitated with sodium hexametaphosphate in an ultrasonic bath to create a suspension of suitable density, seived to remove the $>900 \mu \mathrm{m}$ fraction and repeatedly flushed through a Coulter LS100 Laser Diffractometer to derive size-frequency data.

\section{Results}

\section{Bedrock}

The underlying strata in the field area are polydeformed Neoproterozoic metasedimentary rocks of the Dalradian Supergroup, which comprise mainly metasandstone and metasiltstone, with less abundant interbedded pelitic and calcareous rocks. Deformation of the bedrock has resulted in wide variation in its dip and strike, although the regional strike is approximately $\mathrm{W}-\mathrm{E}$ in the south and SW - NE further north. Bedrock is easily discernable almost everywhere, due to the mainly thin covering of superficial deposits. In many places the bedrock is highly abraded, smoothed or polished, reflecting the legacy of successive glacial episodes. Particularly clear examples of ice-smoothed bedrock occur in Lairig Arnan, Gleann nan Caorann, Lairig nan Lunn, and Glen Falloch, on cols between Beinn Dorain and Beinn a' Chreachain, also between Ben Lui and Beinn Dubhchraig, and at higher levels on the flanks of mountains south of Glen Falloch such as Beinn Chabhair, Beinn a' Chroin and Cruach Ardrain (Fig. 2B). Zones of disaggregated bedrock - where blocks have been detached and moved less than a few 10's of metres from source outcrops - occur on some plateau areas between mountain peaks and valley troughs (Fig. 2B). Where the detached blocks form drumlinoid mounds, the former direction of ice flow can be 
inferred. Erosional landforms such as roches moutonnée, P-forms and striae were recorded in Glen Falloch, Lairig Arnan, Loch Easan, Glen Lochay, Coire Chailein and Mam Lorn.

\section{Glacial deposits}

Sedimentology

A description of each facies type encountered, their expression and occurence in the study area, and their genetic interpretations are presented in Table 1. As no formal stratigraphy exists for the study area the facies are differentiated on their colour, texture, composition and internal structure, and are coded here $\mathrm{A}-\mathrm{H}$. This simple approach enables identification and classification of deposits in the field and allows units to be confidently correlated between exposures.

[TABLE 1 HERE]

Facies A, B, C, and D are all well-consolidated generally massive diamictons composed of sand, silt and clay and containing sub-angular and sub-rounded clasts. Facies A, B and D are locally weakly stratified, however, and host centimeter to decimeter-scale pods or laterally-impersistent partings of silt and fine sand, whereas Facies $\mathrm{C}$ is never stratified and has a finer-grained matrix that produces an almost choncoidal cleavage pattern. All of these diamictons are firm or very firm but they differ from one another in their colour and matrix mineralogy. Facies A and B are reddish-brown and yellow-brown respectively, and both contain kaolinite. Facies $\mathrm{C}$ is blue-grey or greenish-grey and contains calcite, whilst Facies D is light olive-brown in colour and contains neither calcite or kaolinite. Facies E and F are similarly-coloured diamictons to Facies D but are considerably less consolidated. They are often stratified, with sand beds up to $1 \mathrm{~m}$ thick in Facies $\mathrm{E}$ and thinner lenses and beds in Facies F. Both diamictons are rich in well-rounded to very angular clasts ranging from gravel and cobbles to boulders.

Facies $\mathrm{G}$ comprises a range of grain-sizes but in all instances is characterized by a high degree of size sorting not seen in the other units. Whilst some units are massive, others show primary sedimentary structures such as planar bedding, trough cross-bedding or lamination. Facies $\mathrm{H}$ is identifiable by the grade of its constituents (boulders) and lack of sedimentary structures. Deposits of this facies are commonly very localised and cannot be laterally correlated. In most cases, however, the other facies $(A-G)$ show remarkable inter-site uniformity, and can be traced across the study area relatively easily, although the number of exposures of each unit is widely variable. For example, Facies A and B were only seen in Coire Thoin and Coire Chailein respectively, but the remainder are considerably more widespread (Table 1). Examples of the 
main facies types and the typical form of ice-smoothed bedrock are shown in Fig. 3A-D, and PSD data for Facies A - D are plotted in Figure 4.

[FIGURES 3 \& 4 HERE]

Stratigraphy

The sediments described in Table 1 are patchily distributed across the study area, but exposed metasedimentary bedrock is widespread. Whilst most valleys have only thin valley-floor till cover, some - such as Coire Chailein, Coire Thoin, Coire Bhiocair, and Glen Auchreoch - host sediment accumulations up to $30 \mathrm{~m}$ thick (Fig. 2B). These thicker sequences provide the basis for facies correlation between sections, and are described in more detail below.

The section exposed in Coire Chailein is shown in Fig. 5. Although some lateral variation occurs, the overall sedimentary sequence can be summarised as follows. The lowest unit, Facies B, is a $12-13 \mathrm{~m}$ thick, very firm, yellow-brown, sandy diamicton containing subangular and subrounded metasedimentary clasts. This is overlain by a complex sequence of interbedded sand, gravel and diamicton units. These are laterally variable in thickness but include an approximately $1 \mathrm{~m}$ thick clast-supported predom inantly sub-angular psammite boulder bed, (Facies H), beds of weakly stratified sandy and gravelly diamicton up to $1 \mathrm{~m}$ thick (Facies F), and an overlying unit of laminated clay, silt and trough-cross-bedded sand 1-2 m thick (Facies G). In places the bedded sand exhibits centimetre-scale faults and folds. Overlying the sand is weakly stratified gravel that grades upward into gravelly diamicton (Facies F), which is then overlain by $8 \mathrm{~m}$ of grey, clayey diamicton (Facies C), and firm, brown, diamicton (Facies D).

[FIGURE 5 HERE]

The dominant sediment exposed in Coire Thoin is Facies A - a cohesive diamicton that in a weathered section appears uniformly reddened, but when dug becomes increasingly yellowbrown with depth. The diamicton is sandier and more clearly stratified higher up, and is overlain by Facies $\mathrm{C}$ diamicton. In Coire Bhiocair the sedimentary infill is poorly-exposed, but appears to consist predominantly of Facies D diamicton. In Glen Auchreoch and Gleann nan Caorann conformable sequences of Facies $\mathrm{C}$ and $\mathrm{D}$ up to $10 \mathrm{~m}$ thick are preserved, the two units separated by abrupt, sub-planar contacts.

Smaller exposures elsewhere are also instructive. In Glen Lochy Facies D is overlain by up to $5 \mathrm{~m}$ of stratified sandy, unconsolidated diamicton (Facies E) containing discrete sand beds up to $1 \mathrm{~m}$ thick. In Cononish Glen and Gleann Auchreoch, moraines are composed of Facies F stratified 
diamictons that dip up-valley, host numerous folded and faulted sand and silt laminae or beds, and in upper Cononish Glen are overlain by Facies G fines. Elsewhere, such as in Balquhidder Glen, Glen Lyon, and Glen Falloch, Facies G is intercalated with laterally impersistent and variably thick diamictons of Facies F.

\section{Facies occurence and spatial distribution}

Figures $6 \mathrm{~A}-\mathrm{C}$ show, respectively, scaled logs of the principal exposures in the study area, intersite correlation of units, and, based on these, the first composite glacial stratigraphy for the region. Note that in many cases there may be several units of the same facies present, representing a stratified deposit that records episodic deposition. In Figure 6A the logs are grouped according to the facies present at each locality in order to facilitate comparison. The horizontal 'baseline' divides deposits interpreted as Younger Dryas in age from those deemed older (cf. Table 1).

From Fig. 6A it is apparent that Facies $\mathrm{A}$ and $\mathrm{B}$ are each only found at one locality, in glens where their preservation suggests that former ice flow was oblique to the valley axis (Golledge, 2007b). In both cases the diamictons occur at the base of the preserved sequences, and are overlain by Facies C. The latter is more widespread than either Facies A or B, but its occurence is nonetheless restricted to isolated 'pockets', such as near Ben Glas, in Gleann nan Caorann, Gleann Auchreoch, Gleann a' Chlachain, Coire Thoin and Coire Chailein. Facies D is ubiquitous and is generally the dominant deposit in most glens.

\section{[FIGURE 6 HERE]}

\section{Landform-sediment assemblages}

Neither Facies A or B are associated with any characteristic topographic expression, but Facies C \& D commonly form both smooth valley-side veneers and compose large, broad, ridges. Facies $\mathrm{E}$ drapes many of these larger ridges, and also composes irregular moundy spreads. The latter are often characterized by abrupt transitions from diamicton to fines, and in many cases exhibit complex faulting and folding. Whilst compositionally similar, Facies $\mathrm{F}$ tends to form distinct sharp-crested moraines, and thus the two facies can be differentiated on the basis of their landform-sediment assemblage and mapped separately. Since these moraines have important implications for reconstructing former glacier dynamics, they are considered in more detail below. 
Moraines include all ridges interpreted to result from direct formation by glacier ice, whether their origin is primarily subglacial (e.g. ribbed moraine), or subaerial (e.g. latero-frontal moraine). Those in the study area can be classified into three types:

Type 1 moraines are typically broad-crested, relatively smooth features that may be $>10 \mathrm{~m}$ high and 10's - 100's metres in length (Fig. 7). Some are bedrock-cored, and may show alignments similar to the structural trend of the underlying strata, for example northwest of Loch Tulla (Fig. 2B). Many Type 1 features, however, are largely composed of cohesive diamictons of Facies $\mathrm{C}$ and D, and may host superficial drapes of more friable Facies E or F diamicton, as well as one or two scattered boulders on their crests. The best examples of these moraines occur in an extensive sub-parallel suite that trends approximately west-east in an arcuate belt $2-3 \mathrm{~km}$ wide, at a height of $350-550 \mathrm{~m}$ a.s.l. on the undulating plateau area south of Ben Lui and Beinn Dubhchraig (Fig. 2B). Landforms within this assemblage, particularly at the western and eastern margins of the plateau, show superimposed lineations that cross-cut or distort their 'parent' ridges. Suites of overridden or streamlined landforms also occur around Loch Easan (Fig. 2B) and Coire Eoghannan (Golledge \& Hubbard, 2005).

Type 2 moraines are generally $<10 \mathrm{~m}$ high and up to a few 10's metres in length, exhibit sharp crests, and are often arcuate across valley floors (Fig. 7). They are predominantly composed of stratified or interdigitated units of Facies F (sandy diamicton) and G (bedded or laminated clay, silt and sand). Contacts between units may be either conformable and planar, or erosive and irregular. In a number of cases small faults, thrusts or folds may be seen, reflecting low strain deformation. The most well-developed moraines occur at the east end of Cononish Glen (Fig. 2B). The abundant steep-sided mounds are typically concave on their north and northeastern sides, and where exposures exist, often exhibit generally southward-vergent glaciotectonic structures. Further west in Cononish Glen abundant moraines occur on the northern valley side, but not on the southern side. Again, vergence of glaciotectonic structures is to the south or southwest. Many of the valley floor moraines near the western end of the glen are composed of stratified diamictons whose architecture is consistently dominated by westward-dipping very clast-rich subunits. Gleann Auchreoch, a tributary of Glen Cononish, hosts well-developed moraines along much of its valley floor. Many of the other glens mapped host at least some Type 2 morainic landforms - other good examples can be seen in upper Auch Gleann, Coire Thoraidh, and Gleann a' Chlachain.

[FIGURE 7 HERE] 
Type 3 moraines are boulder ridges (Fig. 7). These landforms are considerably less abundant than either Type 1 or 2 moraines, and are most prevalent in glens of the Beinn Chabhair - Ben More massif, south of Glen Falloch and Glen Dochart. In lower Coire Earb, for example, low boulder ridges $<5 \mathrm{~m}$ high descend the valley sides in arcuate nested groups that can be traced up-valley to the former glacier source area of Beinn a' Chroin. Type 3 moraines are predominantly composed of locally-derived large boulders, but may overlie diamictons of Facies D or incorporate units of Facies $\mathrm{F}$ or $\mathrm{G}$.

Glaciofluvial and glaciolacustrine deposits (Facies G) rarely form distinct landforms in the study area, but bedded or laminated fine-grained sediments were often found on-lapping, overlying or intercalated with the morainic deposits. In Coire Chailein, Facies G silt and clay units are buried and have no surface expression. In most other cases, however, these sediments form flat terraces located in either intra-moraine areas, or are contiguous with moraines. For example, in Coire Earb Facies G sand and silt form a flat-topped gently north-sloping glaciolacustrine delta. Bedded sand was noted in two places in upper Glen Cononish: dipping south into the hillside north of Ben Oss, and dipping northwestward (up-valley) below Ben Lui. Glaciofluvial fans and terrace remnants were mapped in Glen Orchy, in Strathfillan, and near the head of Loch Lomond. Exposures in Strathfillan reveal southward-dipping bedded sand, and laminated silt and clay. Ice-contact glaciofluvial mounds were recorded near Bridge of Orchy and amongst the moraines at Dalrigh, distinguished by their well-sorted composition.

\section{Interpretation: facies genesis}

The accuracy of any glacier reconstruction depends to a large extent on the accurate interpretation of sedimentological and stratigraphic evidence in a landform-sediment and process-form context. Many recent studies have reviewed the common nomenclature of glacigenic sediments, and with varying scales of focus, have attempted to refine the theories on which genetic interpretations and facies classifications are based (Menzies, 1989; Benn \& Evans, 1996; Krüger \& Kjær, 1999; Piotrowski et al., 2004; Menzies et al., 2006; Evans et al., 2006). The sedimentological character, stratigraphic relations and landform context of the bedrock features and glacial sequences in the western Scottish Highlands are compared below with these studies, and where appropriate, with modern examples. 
Although potentially classifiable as ' $M$ ' beds (Menzies, 1989), 'deformation till' (Benn \& Evans, 1996), 'tectomict' (Menzies et al., 2006), or 'traction till' (Evans et al., 2006), Facies A - D are simply considered here to be of unspecified subglacial origin, for the following reasons: they contain predominantly subangular and subrounded clasts that are often striated, and have a silt and sand-dominated matrix showing a bimodal grain-size distribution. They are very firm in outcrop and closely resemble subglacial till observed at modern glacier margins (e.g. Fig. 8A). Facies $\mathrm{E}$ is similar in composition but is very poorly consolidated. On this basis it is interpreted as 'submarginal', that is, largely derived by reworking of underlying substrates by the glacier sole and by the addition of 'new' material melting-out subglacially, in a manner similar to that shown in Figure 8B. Although such deposits have relatively poor preservation potential compared to more consolidated substrates (Evans et al., 2006), they are found in a number of locations in the study area (Fig. 6A). The presence of planar-bedded sand and silt inclusions within units of Facies $\mathrm{E}$ argues against these units having been pervasively deformed either during or after deposition (Piotrowski et al., 2001).

The stratigraphic position of Facies A and B, together with their very limited preservation and, in the case of Facies A, the presence of clay minerals typical of long-term weathering (kaolinite), suggests that these sediments relate to a significantly earlier phase of glaciation than the one that deposited the more widespread units higher in the sequence. Although distinguished by slight colour differences, Facies A and B are likely to be the same unit, since they share many common characterisics (grain size, composition, mineralogy) and are stratigraphically equivalent.

Since Facies $\mathrm{C}$ has a silt and clay (rock flour) matrix and is very firm, it is interpreted as the product of bedrock erosion by plucking or micro-fracturing (sensu Hutter \& Olunloyo, 1981). This process requires intimate ice-bedrock contact and only sufficient basal meltwater to facilitate sliding. Lower effective overburden pressures (whether due to more basal meltwater or thicker unconsolidated basal substrate) would have prevented such effective bedrock erosion. It is thus inferred that this high shear strength, low permeability grey till is the product of a thick, relatively cold-based, and hence slowly-moving ice mass that transported the material englacially (Fig. 8C $\& \mathrm{D})$.

\section{[FIGURE 8 HERE]}

Facies $\mathrm{C}$ and $\mathrm{D}$ are almost identical in terms of their structure, clast content, and composition, differing only in their matrix grain size and colour. They are never separated by intervening units and the colour contrast is often abrupt and, for example near Ben Glas (Fig. 2A), cross-cuts 
individual clasts (Golledge, 2007a). Metasedimentary bedrock underlies the majority of the field area and thus, even if changes in ice-flow direction and concomitant sediment provenance occurred, they would be unlikely to produce debris of significantly different colour. Since the colour change is seen to cross-cut individual clasts, a plausible explanation may be that the redbrown colour of Facies D reflects a greater concentration of ferrous oxides, produced by postdepositional weathering. Facies $\mathrm{C}$ and $\mathrm{D}$ can thus be interpreted as pertaining to the same glacial advance, an inference supported by interpretations of similar grey-brown till sequences in Canada (Hendry et al., 1984), Sweden (Lagerbäck, 1992), Estonia (Rattas \& Kalm, 2001), Denmark (Christoffersen \& Tulaczyk, 2003) and England (Madgett, 1975; Madgett \& Catt, 1978). These diamictons constitute many of the thickest and most widespread exposures in the area, and compose many of the large Type 1 moraines, consistent with deposition beneath a wellestablished and long-lived ice sheet such as the one known to have existed in Britain during the Main Late Devensian.

Facies $\mathrm{E}$ is widespread in its occurence, is spatially variable in its composition, and is generally less well-consolidated than the Facies D diamicton that it overlies. The presence of bedded sand and silt, conformably stratified within units of Facies E, suggest that these sediments were deposited by flowing water. The presence of well-rounded as well as angular cobbles indicates that debris was derived from both subglacial and supraglacial environments, whilst the lack of cohesion of Facies E suggests that effective ice overburden pressures were relatively small. Facies E may therefore have a complex and variable origin. It is likely that subglacial meltwater eroded and reworked the underlying till sheet (where present) (cf. Piotrowski \& Tulaczyk, 1999), thus giving rise to conformable, and in some instances, transitional contacts between Facies D and $\mathrm{E}$. This must have occurred subsequent to the emplacement of Facies D, and most likely can be attributed to recycling of the older deposits by the Younger Dryas ice cap. During this readvance, debris melting-out from englacial and subglacial transport (Fig. 8B-E) became superimposed on these saturated basal sediments, and were patchily intercalated with well-sorted material deposited from emerging subglacial streams. The high degree of sorting indicates sediment transport as suspended load in water of steady velocity, flowing either in well-defined subglacial channels or through a network of linked cavities. Sheet flow is considered unlikely given the inherent instability of such systems (Fountain \& Walder, 1998). Laterally impersistant bedded sand bodies up to $1 \mathrm{~m}$ in thickness in Facies $\mathrm{E}$ lend support to the notion of low-pressure cavities, canals or lakes at the glacier bed, where decreased flow velocities enabled sediment deposition. Such features have been recorded in ancient till sequences elsewhere, for example in 
North America (e.g. Clayton et al., 1989). Whilst compositionally similar to Facies F and G that overlie it, Facies E commonly exhibits primary sedimentary bedding and rarely shows convolutions and glaciotectonic deformation, suggesting a relatively passive depositional environment.

Marginal recession accompanying Younger Dryas deglaciation also led to deposition of material from supraglacial sources in the ice-marginal environment, where debris flows from the ice surface augmented deposits of ablated basal ice (Fig. 8F). These deposits are distinguished here as Facies $\mathrm{F}$ where they form Type 2 moraine mounds and ridges, comparable to those found at contemporary ice margins (Fig. 8G). These poorly-consolidated heterogenous deposits are commonly associated with retreat of the Younger Dryas ice cap in Scotland, albeit with interpretations of genesis ranging from melt-out of stagnant debris-rich ice to thrusting at the margins of actively retreating glaciers (see Lukas, 2005a,b, for a comprehensive review). Recent research tends to agree, however, that the abundance and close spacing of such moraine mounds are indicative of actively retreating, high mass-turnover ice that is close to equilibrium (Thorp, 1991a; Benn \& Ballantyne, 2005; Benn \& Lukas, 2006).

Widespread intercalation of Facies G with Facies F, commonly near the top of the stratigraphic sequence, suggests that ice-proximal deposition by glaciofluvial drainage was, at least initially, contemporaneous with ice-marginal debris flows. As sediment supply waned, however, probably as a result of ice margin recession, ice marginal ponds developed and accumulated the uppermost laminated and bedded sediments. Facies $\mathrm{G}$ in Coire Chailein, however, intervenes between subglacial till units. For this reason is suggested that it was deposited during an early phase of ice recession that enabled sub-aerial deposition of the trough-cross-bedded sand and stratified gravel unit, probably in a braided fluvial or ice-marginal glaciofluvial system prior to the Main Late Devensian glacial advance. This scenario is corroborated by preliminary results from luminescence dating of the sediments (Golledge \& Robinson, 2007).

In summary, it is suggested that Facies A \& B pre-date the Main Late Devensian glaciation, that Facies C \& D are the subglacial product of the MLD glaciation, and that Facies E and surface occurences of Facies F were deposited by glaciers of the Younger Dryas readvance. Facies G \& $\mathrm{H}$ occur at different stratigraphic levels within the sedimentary sequence and reflect depositional processes common to each glacial advance. 


\section{Discussion: Glacier dynamics in the western Scottish Highlands}

The sediments and their stratigraphic relations described above enable a composite stratigraphy to be constructed for the first time in this area (Fig. 6C), and allow the following inferences to be made with respect to the evolution of ice masses and former glacier dynamics in the study area. Areas of scoured bedrock and the isolated cases of sediment preservation represent opposing end members of the erosion-deposition continuum, thus their respective distribution can be used to infer basal conditions beneath the ice.

That scoured or simply bare bedrock surfaces are widespread in the area indicates that the last ice to overwhelm the study area - the Younger Dryas ice cap - largely rested on a rigid bed. The ice mass therefore only flowed over a deformable bed in very restricted portions of the study area, and it deposited relatively little substrate during its subsequent retreat. This is consistent with much of the field area occurring beneath the central portion of the former Younger Dryas ice cap. Ice-flow during this episode was accomodated in some areas through ice deformation (creep or shear) and meltwater lubrication at the ice-bed interface. Where ice deformation was the dominant process, flow would have been slow and largely non-erosive, governed mainly by the temperature-dependent creep rate of the ice. The presence of areal bedrock scouring, fluting of both bedrock and unconsolidated deposits, roches moutonnée, P-forms, and striae all indicate more rapid ice flow and at least some erosion of the bed (Hall \& Glasser, 2003; Roberts \& Long, 2005), suggesting that some parts of the ice cap flowed by meltwater-lubricated basal sliding. This is known to have occurred elsewhere where streamlined bedrock features have been preserved (Glasser, 2002; Stoker \& Bradwell, 2005; Roberts \& Long, 2005).

Whether bedrock smoothing is partially inherited, isochronous, or time-transgressive is difficult to determine without, for example, cross-cutting striae. Thus it is not possible from this evidence alone to determine the evolution of the basal thermal regime during the lifetime of the Younger Dryas ice cap, only that it must have been at least partially warm-based at some point, and probably most extensively during the warming period that accompanied deglaciation. This inference does not, however, preclude the very likely possibility that flow mechanisms evolved throughout the lifetime of the ice cap. The field evidence is, therefore, a time-transgressive assemblage that superimposes features pertaining to the last phase of glacial activity on a preexisting, Main Late Devensian, landscape. The juxtaposition of scoured bedrock in some areas 
with preservation of older sediments in others suggests convincingly that processes operating at the glacier bed were spatially (and so probably also temporally) variable, such as is typical of glacial environments (Piotrowski et al., 2004).

Sutherland (1993) asserted that, 'no deposits older than the Loch Lomond Stadial' are known in this part of the western Scottish Highlands, and thus the recognition of superimposed Main Late Devensian landforms, their constituent sediments, and the discovery of two sequences containing sediments that even pre-date the Main Late Devensian is particularly significant. Since these older deposits have not been removed, later ice flow in these parts of the study area must have been accomodated either through ice deformation, sliding, or by deformation of only a thin zone of the bed. Deposition of Facies C, a rock-flour dominated subglacial till, reflects intimate icebed contact during the build-up of the Main Late Devensian ice sheet (Fig. 9A) which may have persisted until glacier sliding was inhibited, perhaps by extreme cold and increased aridity. Without high mass turnover the ice sheet may have become largely immobile in this area and probably frozen to much of its bed. Landscape preservation associated with former frozen bed conditions is widely reported from Scandinavia (e.g. Kleman, 1994; Kleman \& Borgstrom, 1994; Kleman \& Hättestrand, 1999), and thus may be an equally plausible scenario for this central portion of the former British Ice Sheet.

[FIGURE 9 HERE]

Deposition of subglacial till continued during deglaciation, but, as a result of higher velocity meltwater flow that preferentially removed silt and clay (Alley et al., 1997), was characterized by a coarser matrix. This subsequently controlled downward migration of the post-depositional weathering front that produced the colour contrast that distinguishes Facies D. Areas of scoured bedock in the study area may partly have been produced by accelerating ice sheet flow and the presence of fast-flowing outlet glaciers during deglaciation, both catalysed by enhanced meltwater-lubricated sliding (Fig. 9B). Together with localised deformation of dilatant unconsolidated substrates, this led to dynamic lowering of the ice sheet surface.

Widespread preservation of sediments and the streamlining of Late Devensian landforms in the study area reflects the restricted basal erosion that took place during the Younger Dryas. This last period of glaciation also failed to deposit a distinct subglacial till of it own, instead reworking and remoulding older sediments. Lenses and beds of sand and fine gravel in Facies E record localised, possibly channelised, subglacial meltwater flow, and testify to limited deformation of the substrate following their deposition. The demise of the Younger Dryas ice cap is thought to have 
resulted from a rapid climatic amelioration that abruptly terminated the steady cooling of the early part of the stadial (Clapperton, 1997; Hubbard, 1999). Non-topographically aligned moraines in many glens provide convincing evidence that the ice mass decayed as a coherent ice cap in much of this area, most probably supporting a relatively steep marginal gradient that even during retreat was able to overwhelm topographic barriers (Golledge, 2007b). Glaciotectonic indicators in many of the moraines and intercalated outwash deposits attest to the dynamic nature of the retreating ice margin, even at this close proximity to its main source areas surrounding Rannoch Moor. To enable this, the warming climate must have been accompanied by sufficient precipitation to continually nourish the receding ice mass to a level adequate to significantly abate surface lowering.

That the uppermost units in many of the recorded sedimentary exposures show laminated or bedded fine sediments (Facies G) interdigitated with coarser diamictons (Facies F) may either reflect oscillations of the retreating ice margin, or climatically-controlled changes in meltwater and concomitant sediment flux. Either way, the abundance of laminated fine-grained sediments in many of the glens indicates that final deglaciation took place in a very wet environment characterized by widespread ephemeral proglacial ponding (Fig. 9C). Poor connectivity between glacial and fluvial systems has been documented in Younger Dryas landsystems elsewhere in Scotland (Benn \& Lukas, 2006), and may be equally applicable here. This is further supported by the relative paucity of glaciofluvial outwash deposits seen in the study area.

Final disappearance of ice from the study area occurred after 11.6 $\pm 1.0 \mathrm{ka}$ BP (Golledge et al., 2007), and may well have broadly coincided with the Younger Dryas climatic termination identified in ice cores at c. $11.3 \mathrm{ka}$ (Alley, 2000).

\section{Conclusions}

Geological mapping, section logging and laboratory analysis has allowed a suite of eight distinctive glacial sediment facies to be identified. This has enabled, for the first time, a coherent glacial stratigraphy to be defined for part of the western Scottish Highlands that encompasses deposits spanning three glacial episodes. Widespread preservation of these sediments, and the landforms that they compose, indicates that former ice masses in this area were less erosive than previously envisaged, and that the present landscape constitutes a 'palimpsest' in which features 
of different ages are superimposed. When considered in their proper context, the landsystem elements indicate that glacier flow over a deformable bed was considerably more prevalent during the Late Devensian than the subsequent Younger Dryas, when instead ice movement may have been governed to a larger extent by meltwater-lubricated basal sliding. These new insights into the former behaviour of ice masses in the area enable better comparison with deglaciated landscapes elsewhere, and provide a testable model for future glaciological modelling experiments.

\section{Acknowledgements}

I am especially grateful to Ann Mennim for laboratory assistance, and to Ruth Robinson, David Sugden and numerous BGS colleagues for useful discussions in the field. Constructive reviews by Emrys Phillips, Andrew McMillan, Jez Everest and Jan Piotrowski improved the paper. This paper is published with the permission of the Executive Director of BGS. 


\section{References}

Agassiz, L. 1841. On glaciers, and the evidence of their having once existed in Scotland, Ireland, and England. Proceedings of the Geological Society of London, 3, 327-332.

Alley, R. B., \& MacAyeal, D. R. 1994. Ice-rafted debris associated with binge purge oscillations of the Laurentide Ice-Sheet. Paleoceanography, 9, 503-511.

Alley, R. B., Cuffey, K. M., Evenson, E. B., Strasser, J. C., Lawson, D. E., \& Larson, G. J. 1997. How glaciers entrain and transport basal sediment: Physical constraints. Quaternary Science Reviews, 16, 1017-1038.

Alley, R.B. 2000. The Younger Dryas cold interval as viewed from central Greenland. Quaternary Science Reviews, 19, 213-226.

Anderson, J. B., Shipp, S. S., Lowe, A. L., Wellner, J. S., \& Mosola, A. B. 2002. The Antarctic Ice Sheet during the Last Glacial Maximum and its subsequent retreat history: a review. Quaternary Science Reviews, 21, 49-70.

Ballantyne, C. K. 1997. The periglacial geomorphology of Scotland. p166-178 of: Gordon, J. E. (ed), Reflections on the Ice Age in Scotland: an Update on Quaternary Studies. Glasgow: Scottish Association of Geography Teachers and Scottish Natural Heritage.

Barnard, P. L., Owen, L. A., \& Finkel, R. C. 2006. Quaternary fans and terraces in the Khumbu Himal south of Mount Everest: their characteristics, age and formation. Journal of the Geological Society, London, 163, 383-399.

Benn, D. I. 1994. Fluted moraine formation and till genesis below a temperate valley glacier Slettmarkbreen, Jotunheimen, southern Norway. Sedimentology, 41, 279-292.

Benn, D. I., \& Ballantyne, C. K. 2005. Palaeoclimatic reconstruction from Loch Lomond Readvance glaciers in the West Drumochter Hills, Scotland. Journal of Quaternary Science, 20, $577-592$. 
Benn, D. I., \& Evans, D. J. A. 1996. The interpretation and classification of subglacially deformed materials. Quaternary Science Reviews, 15, 23-52.

Benn, D.I., \& Lukas, S. 2006. Younger Dryas glacial landsystems in western Scotland: possible modern analogues and palaeoclimatic implications. Quaternary Science Reviews, 25, 2390 2408.

Benn, D.I., Lowe, J.J., \& Walker, M.J.C. 1992. Glacier response to climatic change during the Loch Lomond Stadial and early Flandrian: geomorphological and palynological evidence from the Isle of Skye, Scotland. Journal of Quaternary Science, 7, 125-144.

Charlesworth, J. K. 1955. Late-glacial history of the Highlands and Islands of Scotland. Transactions of the Royal Society of Edinburgh, 62, 769-928.

Christoffersen, P., \& Tulaczyk, S. 2003. Signature of palaeo-ice-stream stagnation: till consolidation induced by basal freeze-on. Boreas, 32, 114-129.

Clapperton, C.M. 1997. Greenland ice cores and North Atlantic sediments: implications for the last glaciation in Scotland. p45-58 of: Gordon, J.E. (ed), Reflections on the ice age in Scotland: an update on Quaternary Studies. Scottish Association of Geography Teachers and Scottish Natural Heritage.

Clark, C. D. 1997. Reconstructing the evolutionary dynamics of former ice sheets using multitemporal evidence, remote sensing and GIS. Quaternary Science Reviews, 16, 1067-1092.

Clark, C.D., Evans, D.J.A., Khatwa, A., Bradwell, T., Jordan, C.J., Marsh, S.H., Mitchell, W.A., \& Bateman, M.D. 2004. Map and GIS database of glacial landforms and features related to the last British Ice Sheet. Boreas, 33, 359-375.

Clayton, L., Mickelson, D. M., \& Attig, J.W. 1989. Evidence against pervasively deformed bed material beneath rapidly moving lobes of the southern Laurentide Ice-Sheet. Sedimentary Geology, 62, 203-208. 
Dansgaard, W., Johnsen, S. J., Clausen, H.B., Dahl-Jensen, D., Gundestrup, N. S., Hammer, C.U., Hvidberg, C.S., Steffensen, J.P., Sveinsbjörnsdottir, A.E., Jouzel, J., \& Bond, G. 1993. Evidence for general instability of past climate from a 250-kyr ice-core record. Nature, 364, 218-220.

Evans, D. J. A., Phillips, E. R., Hiemstra, J. F., \& Auton, C. A. 2006. Subglacial till: formation, sedimentary characteristics and classification. Earth-Science Reviews, 78, 115- 176.

Evans, D.J.A., Clark, C. D., \& Mitchell, W. A. 2005. The last British Ice Sheet: A review of the evidence utilised in the compilation of the Glacial Map of Britain. Earth-Science Reviews, 70, 253-312.

Eyles, N., \& Miall, A. D. 1984. Glacial facies. p15-38 of: Walker, R.G. (ed), Facies Models. Geoscience Canada Reprint Series, no. 1. Geological Association of Canada.

Eyles, N., Miall, A. D., \& Eyles, C. H. 1984. Lithofacies types and vertical profile models - an alternative approach to the description and environmental interpretation of glacial diamict and diamictite sequences - Reply. Sedimentology, 31, 891-898.

Fountain, A. G., \& Walder, J. S. 1998. Water flow through temperate glaciers. Reviews of Geophysics, 36, 299-328.

Geikie, A. 1863. On the glacial drift of Scotland. Transactions of the Geological Society of Glasgow, 1, 1-190.

Glasser, N. F. 2002. The large roches moutonnées of Upper Deeside. Scottish Geographical Journal, 118, 129-138.

Glasser, N. F., \& Bennett, M. R. 2004. Glacial erosional landforms: origins and significance for palaeoglaciology. Progress in Physical Geography, 28, 43-75.

Golledge, N.R. 2007a. (in press) The Loch Lomond Stadial glaciation south of Rannoch Moor: new evidence and palaeoglaciological insights. Scottish Geographical Journal. 
Golledge, N.R. 2007b. An ice cap landsystem for palaeoglaciological reconstructions: characterizing the Younger Dryas in western Scotland. Quaternary Science Reviews, 26, 213 229.

Golledge, N.R., \& Hubbard, A. 2005. Evaluating Younger Dryas glacier reconstructions in part of the western Scottish Highlands: a combined empirical and theoretical approach. Boreas, 34, 274 286.

Golledge, N.R., \& Robinson, R.A. J. 2007. OSL dating of glaciotectonised sand deposits from Coire Chailein: evidence of multiple glacial episodes preserved in an ice sheet core area. p29 of: The Growth, Maximum Extent and Decay of the Last British and Irish Ice Sheets: Abstracts volume. Quaternary Research Association Annual Discussion Meeting, St. Andrews.

Golledge, N.R., Fabel, D., Everest, J.D., Freeman, S., \& Binnie, S. 2007. (in press) First cosmogenic ${ }^{10} \mathrm{Be}$ age constraint of the timing of Younger Dryas glaciation and ice cap thickness, western Scottish Highlands. Journal of Quaternary Science.

Hall, A. M., \& Glasser, N. F. 2003. Reconstructing the basal thermal regime of an ice stream in a landscape of selective linear erosion: Glen Avon, Cairngorm Mountains, Scotland. Boreas, 32, 191-207.

Hendry, M. J., McCready, R. G. L., \& Gould, W. D. 1984. Distribution, source and evolution of nitrate in a glacial till of southern Alberta, Canada. Journal of Hydrology, 70, 177-198.

Hinxman, L. W., Carruther, R. G., \& MacGregor, M. 1923. The Geology of Corrour and the Moor of Rannoch. Memoir of the Geological Survey of Great Britain. Edinburgh: HMSO.

Hodgkins, R. 1997. Glacier hydrology in Svalbard, Norwegian High Arctic. Quaternary Science Reviews, 16, 957-973.

Horsfield, B.R. 1983. The deglaciation pattern of the Western Grampians of Scotland. Unpublished Ph.D thesis, University of East Anglia. 
Hubbard, A. 1999. High-resolution modeling of the advance of the Younger Dryas ice sheet and its climate in Scotland. Quaternary Research, 52, 27-43.

Hubbard, A., Hein, A. S., Kaplan, M. R., Hulton, N. R. J., \& Glasser, N. 2005. A modelling reconstruction of the last glacial maximum ice sheet and its deglaciation in the vicinity of the Northern Patagonian Icefield, South America. Geografiska Annaler, 87A, 375-391.

Hutter, K., \& Olunloyo, V. O. S. 1981. Basal stress concentrations due to abrupt changes in boundary conditions: a cause for high till concentration at the bottom of a glacier. Annals of Glaciology, 2, 29-33.

Isarin, R.F.B., \& Renssen, H. 1999. Reconstructing and modelling Late Weichselian climates: the Younger Dryas in Europe as a case study. Earth-Science Reviews, 48, 1-38.

Jansson, P., Hock, R., \& Schneider, T. 2003. The concept of glacier storage: a review. Journal of Hydrology, 282, 116-129.

Jones, T. 1998. Empirical testing of Loch Lomond Stadial glacier limits derived from a glaciological model for the Applecross Peninsula, Wester Ross, Scotland. Scottish Geographical Magazine, 114, 164-171.

Kleman, J. 1994. Preservation of landforms under ice sheets and ice caps. Geomorphology, 9, 1932.

Kleman, J., \& Borgstrom, I. 1994. Glacial landforms indicative of a partly frozen bed. Journal of Glaciology, 40, 255-264.

Kleman, J., \& Hättestrand, C. 1999. Frozen-bed Fennoscandian and Laurentide ice sheets during the Last Glacial Maximum. Nature, 402, 63-66.

Krüger, J. 1996. Moraine ridges formed from subglacial frozen-on sediment slabs and their differentiation from push moraines. Boreas, 25, 57-63. 
Krüger, J., \& Kjær, K. H. 1999. A data chart for field description and genetic interpretation of glacial diamicts and associated sediments - with examples from Greenland, Iceland, and Denmark. Boreas, 28, 386-402.

Lagerbäck, R. 1992. Dating of Late Quaternary faulting in northern Sweden. Journal of the Geological Society, London, 149, 285-291.

Lowe, A. L., \& Anderson, J. B. 2003. Evidence for abundant subglacial meltwater beneath the paleo-ice sheet in Pine Island Bay, Antarctica. Journal of Glaciology, 49, 125-138.

Lukas, S. 2005a. A test of the englacial thrusting hypothesis of 'hummocky' moraine formation: case studies from the northwest Highlands, Scotland. Boreas, 34, 287-307.

Lukas, S. 2005b. Younger Dryas moraines in the NW Highlands of Scotland: genesis, significance and potential modern analogues. Unpublished Ph.D thesis, University of St. Andrews.

Madgett, P. A. 1975. Re-interpretation of Devensian Till stratigraphy of eastern England. Nature, 253, 105-107.

Madgett, P. A., \& Catt, J. A. 1978. Petrography, stratigraphy and weathering of Late Pleistocene tills in East Yorkshire, Lincolnshire and North Norfolk. Proceedings of the Yorkshire Geological Society, 42, 55-108.

Mayle, F. E., Bell, M., Birks, H. H., Brooks, S. J., Coope, G. R., Lowe, J. J., Sheldrick, C., Shijie, L., Turney, C. S. M., \& Walker, M. J. C. 1999. Climate variations in Britain during the last Glacial-Holocene transition (15.0-11.5 cal ka BP): comparison with the GRIP ice-core record. Journal of the Geological Society, 156, 411-423.

Menzies, J. 1989. Subglacial hydraulic conditions and their possible impact upon subglacial bed formation. Sedimentary Geology, 62, 125-150. 
Menzies, J., van der Meer, J. J. M., \& Rose, J. 2006. Till - as a glacial "tectomict", its internal architecture, and the development of a "typing" method for till differentiation. Geomorphology, $75,172-200$.

Merritt, J. W., Auton, C. A., \& Firth, C. R. 1995. Ice-proximal glaciomarine sedimentation and sea-level change in the Inverness area, Scotland - a review of the deglaciation of a major ice stream of the British Late Devensian Ice-Sheet. Quaternary Science Reviews, 14, 289-329.

Mitchell, W.A. 1994. Drumlins in ice sheet reconstructions, with reference to the western Pennines, northern England. Sedimentary Geology, 91, 313-331.

Piotrowski, J. A., \& Tulaczyk, S. 1999. Subglacial conditions under the last ice sheet in northwest Germany: ice-bed separation and enhanced basal sliding? Quaternary Science Reviews, 18, $737-$ 751.

Piotrowski, J. A., Mickelson, D. M., Tulaczyk, S., Krzyszkowski, D., \& Junge, F. W. 2001. Were deforming subglacial beds beneath past ice sheets really widespread? Quaternary International, $86,139-150$.

Piotrowski, J. A., Larsen, N. K., \& Junge, F. W. 2004. Reflections on soft subglacial beds as a mosaic of deforming and stable spots. Quaternary Science Reviews, 23, 993-1000.

Rattas, M., \& Kalm, V. 2001. Lithostratigraphy and distribution of tills in the Saadjärve drumlin field, east-central Estonia. Proceedings of the Estonian Academy of Sciences, Geology, 50, 24 42.

Roberts, D. H., \& Long, A. J. 2005. Streamlined bedrock terrain and fast ice flow, Jakobshavns Isbrae, West Greenland: implications for ice stream and ice sheet dynamics. Boreas, 34, 25-42.

Sissons, J. B. 1965. Quaternary of Scotland. p467-503 of: Craig, G. Y. (ed), The Geology of Scotland. Edinburgh: Oliver \& Boyd.

Stoker, M., \& Bradwell, T. 2005. The Minch palaeo-ice stream, NW sector of the British-Irish Ice Sheet. Journal of the Geological Society, 162, 425-428. 
Sugden, D. E. 1977. Reconstruction of the morphology, dynamics, and thermal characteristics of the Laurentide Ice Sheet at its maximum. Arctic And Alpine Research, 9, 21-47.

Sutherland, D. G. 1993. South-west Highlands: Introduction. p307 - 310 of: E., Gordon J., \& Sutherland, D. G. (eds), Quaternary of Scotland. Geological Conservation Review, vol. 6. Scottish Natural Heritage.

Thompson, K.S.R. 1972. The last glaciers of Western Perthshire. Unpublished Ph.D thesis, University of Edinburgh.

Thorp, P.W. 1984. The glacial geomorphology of part of the western Grampians of Scotland with especial reference to the limits of the Loch Lomond Advance. Unpublished Ph.D thesis, City of London Polytechnic.

Thorp, P.W. 1986. A mountain icefield of Loch Lomond Stadial age, western Grampians, Scotland. Boreas, 15, 83-97.

Thorp, P.W. 1987. Late Devensian ice sheet in the western Grampians, Scotland. Journal of Quaternary Science, 2, 103-112.

Thorp, P.W. 1991a. The glaciation and glacial deposits of the western Grampians. p137-149 of: Ehlers, J., Gibbard, P. L., \& Rose, J. (eds), Glacial Deposits in Great Britain and Ireland. Rotterdam: Balkema.

Thorp, P.W. 1991b. Surface profiles and basal shear stresses of outlet glaciers from a Lateglacial mountain ice field in western Scotland. Journal of Glaciology, 37, 77-88.

Van Tatenhove, F. G. M., Fabre, A., Greve, R., \& Huybrechts, P. 1996. Modelled ice-sheet margins of three Greenland ice-sheet models compared with a geological record from ice marginal deposits in central West Greenland. Annals of Glaciology, 23, 52-58. 


\section{Table and Figure captions}

Table 1: Characteristics of the eight facies types described in the text, including postulated genetic interpretations and inferences of depositional environment. Facies codes after Eyles \& Miall (1984); Eyles et al. (1984).

Figure 1: Location map showing area of study in Scottish context, and in relation to approximate maximal extent of Younger Dryas ice cover (after Ballantyne, 1997).

Figure 2: A: The study area, showing principal mountains, valleys and water bodies, and the locations of sediment exposures reported here. Digital terrain model built from Intermap Technologies NEXTMap 1.5m resolution topographic data. B: Occurence of key bed-types in the study area, showing areas of bedrock at or near surface, ice-smoothed bedrock, disaggregated bedrock, thick till accumulations, suites and types of moraine. Some generalisation has been necessary and some smaller occurrences are not shown. Erosional landforms such as roches moutonnée, P-forms, and striations are shown with arrows indicating the inferred former ice flow direction. Northern and eastern margins show Lat / Long; southern and western margins show British National Grid references.

Figure 3: Field photographs showing A: Facies C and D, B: Facies F and G, C: Facies E and F, and D: ice-smoothed metasedimentary bedrock at 560m a.s.1, Glen Orchy (former iceflow approximately right to left).

Figure 4: Particle size distribution curves for sub- $900 \mu \mathrm{m}$ fraction of matrix material from Facies A - D, interpreted as subglacial tills. Note the difference between each plot, and the degree of internal consistency.

Figure 5: Sketch of exposure in Coire Chailein, traced from a photo-montage. Section reveals complex stratigraphy of diamictons (Facies B, C, D, F) interbedded with overridden gravel, sand and silt units (Facies $\mathrm{G}$ ) and a $1 \mathrm{~m}$ thick boulder bed (Facies $\mathrm{H}$ ).

Figure 6: A: Compiled logs of sedimentary units at 53 localities in the study area showing the relative thickness of each facies type. B: Correlation of units between sites where the thickest sequences were recorded. C: Composite stratigraphy for the whole study area. Note that in A, 
sections NRG152, 160 and 188 are truncated to reduce overall length, and that the scale of logs NRG152 and NRG160 is reduced 50\% to facilitate display and comparison with others. In C the vertical scale is approximate and intended to show typical unit thicknesses for comparison with each other. Grain-size depictions are intended to summarize key characteristics of the facies present.

Figure 7: Moraine types and their typical geomorphological context in the study area. Annotations show generalised composition and approximate scale of features.

Figure 8: Examples of facies types, their various transport pathways and depositional environments at modern glaciers. A: Cohesive subglacial till exposed at the retreating margin of Solheimajökull, Iceland. B: Melt-out of subglacial debris from the sole of a retreating glacier, Solheimajökull, Iceland. Note the poor sorting and surface cobbles. C: Folded and attenuated fine-grained englacial debris bands, Longyearbreen, Svalbard. D: Fine-grained debris bands and pod of matrix-dominated diamicton probably incorporated subglacially, Longyearbreen, Svalbard. E: Angular debris band of coarse clasts and gravelly matrix buried supraglacially and incorporated into glacier ice, Longyearbreen, Svalbard. F: The very wet glacier foreland of Steinholtsjökull, Iceland, showing proglacial lakes, sandur, and debris-covered medial moraine. G: Recently vacated ice-margin position, marked by a moraine of poorly-consolidated diamicton, Svinafellsjökull, Iceland.

Figure 9: Conceptual model of the formation of the stratigraphic sequence described in the text. A: Advance of Main Late Devensian ice overwhelms topography and preserves preexisting sediments only in topographic hollows. Intimate ice-bed contact produces rock-flour that is deposited as Facies C, grey subglacial till. B: Changes in the meltwater flux at the glacier bed during deglaciation lead to greater ice-bed separation and the deposition of the coarser-grained Facies D subglacial till. C: Younger Dryas glaciation reworks the upper substrate and adds new material via melt-out from the glacier sole (Facies E) and the emplacement of subaerial debris flows (Facies F). Ice-marginal lakes form in the warming climate and allow gradual settling-out of fine-grained suspended sediment (Facies G). 


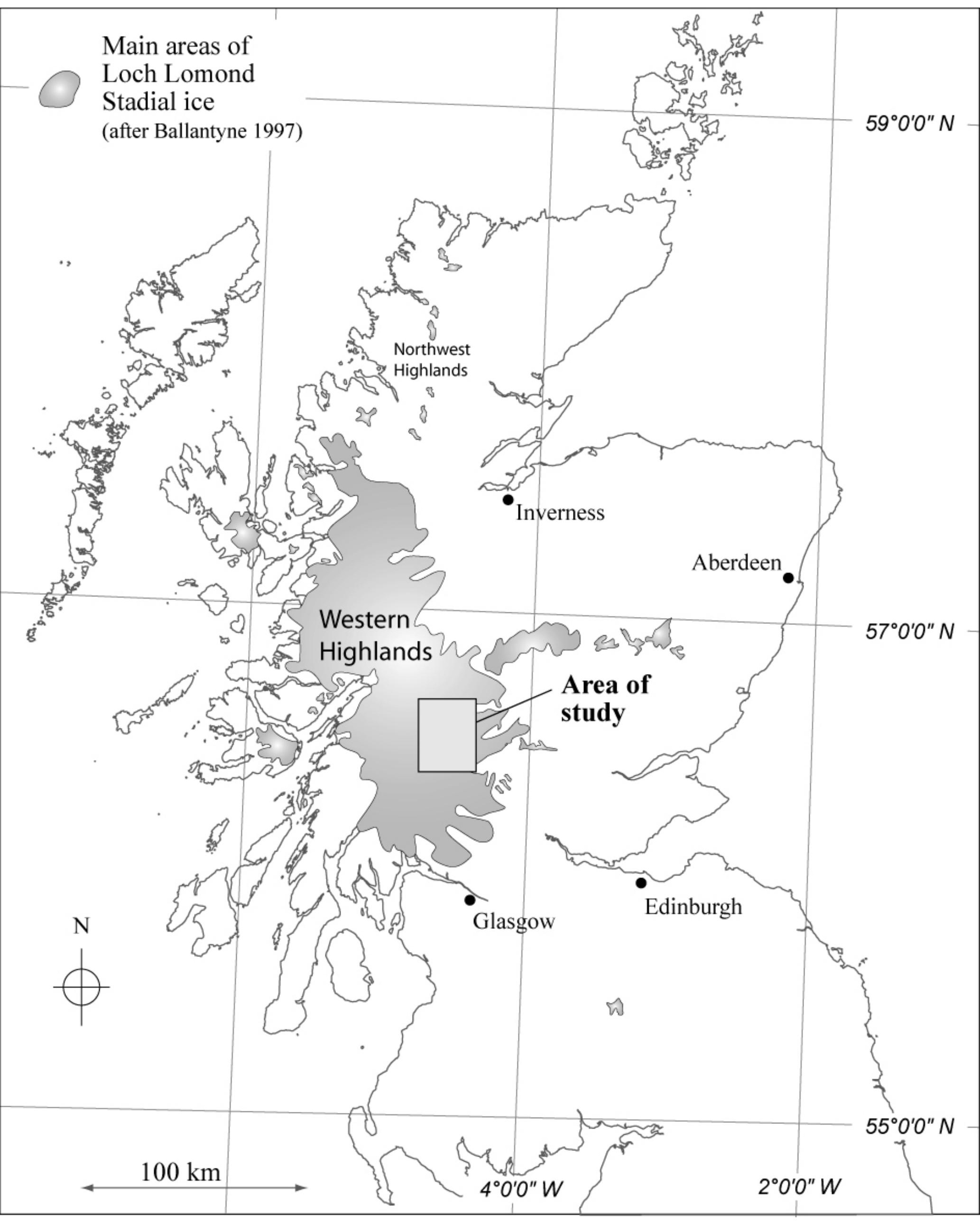



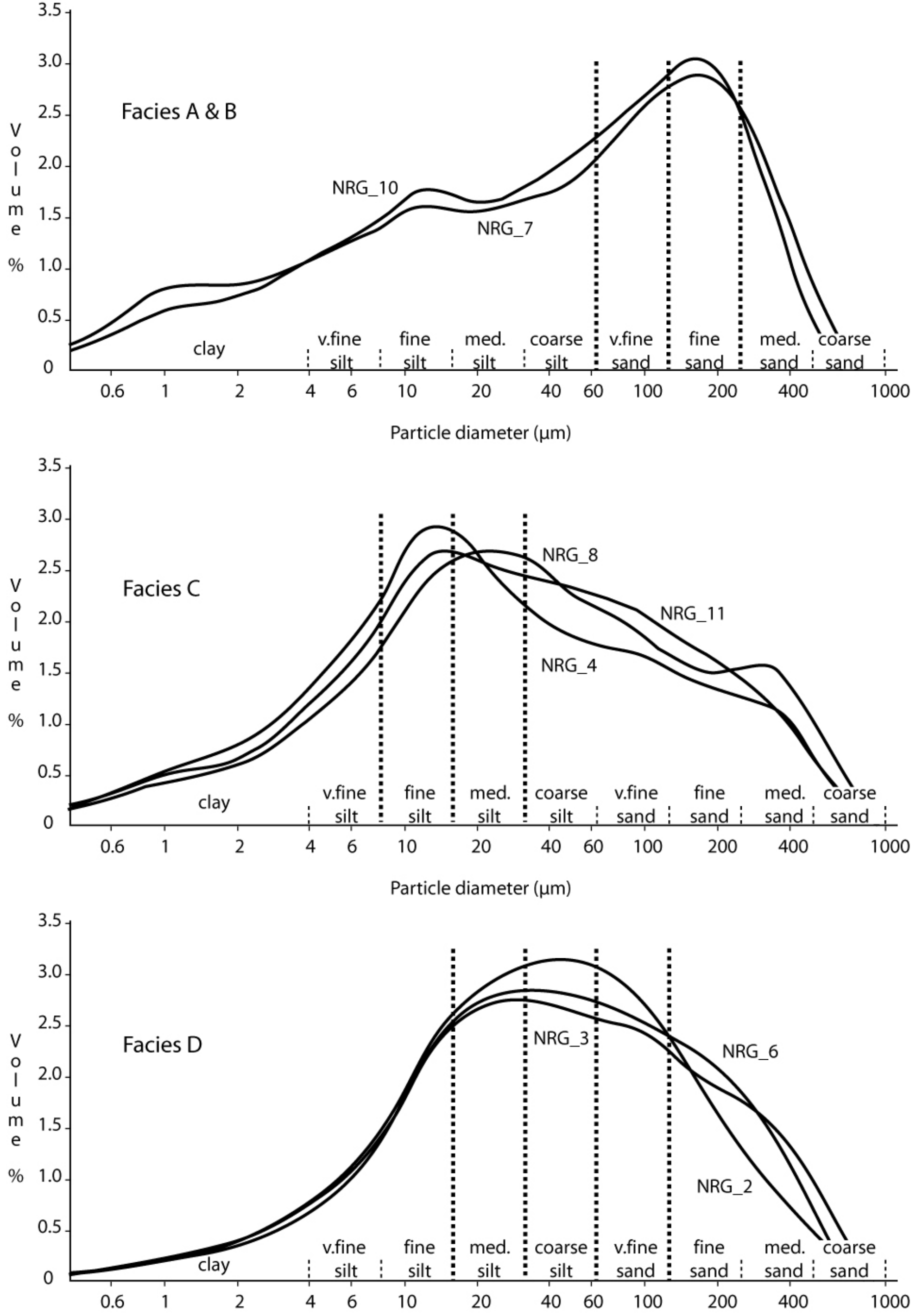

Particle diameter $(\mu \mathrm{m})$ 


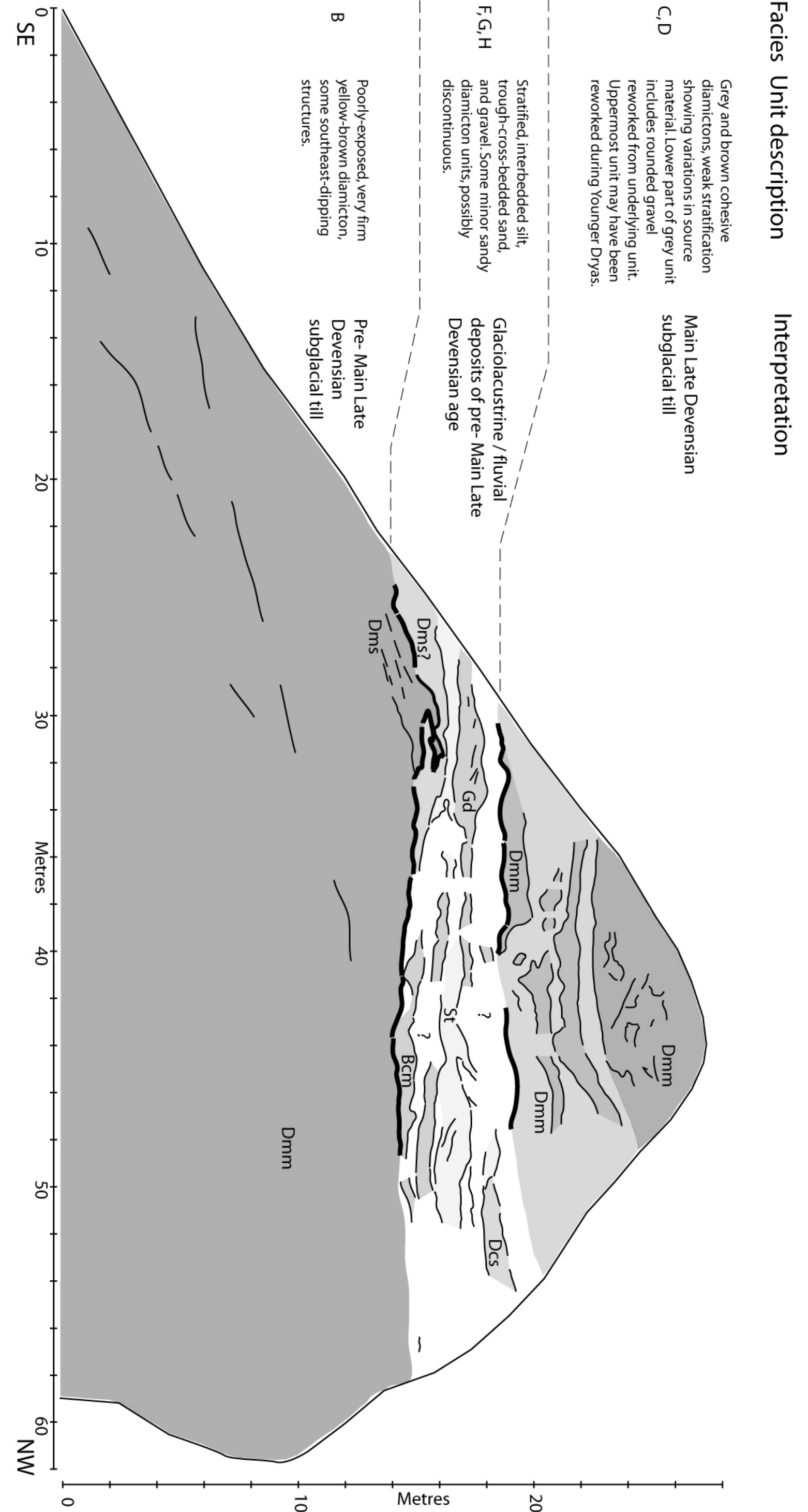




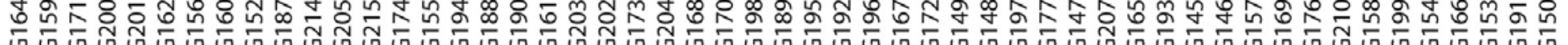

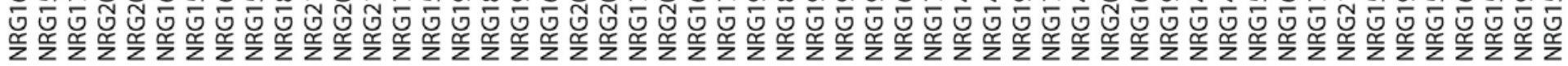

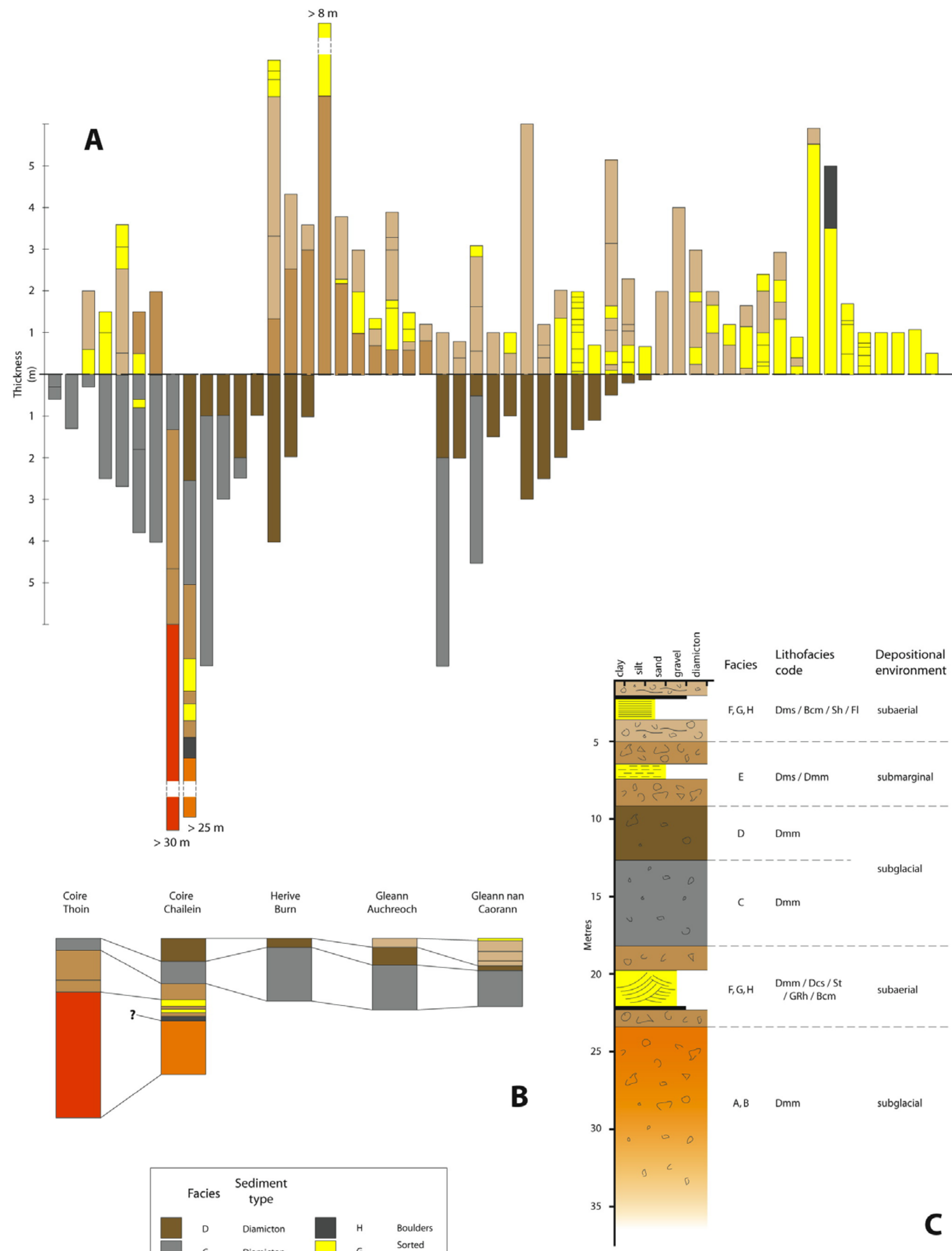




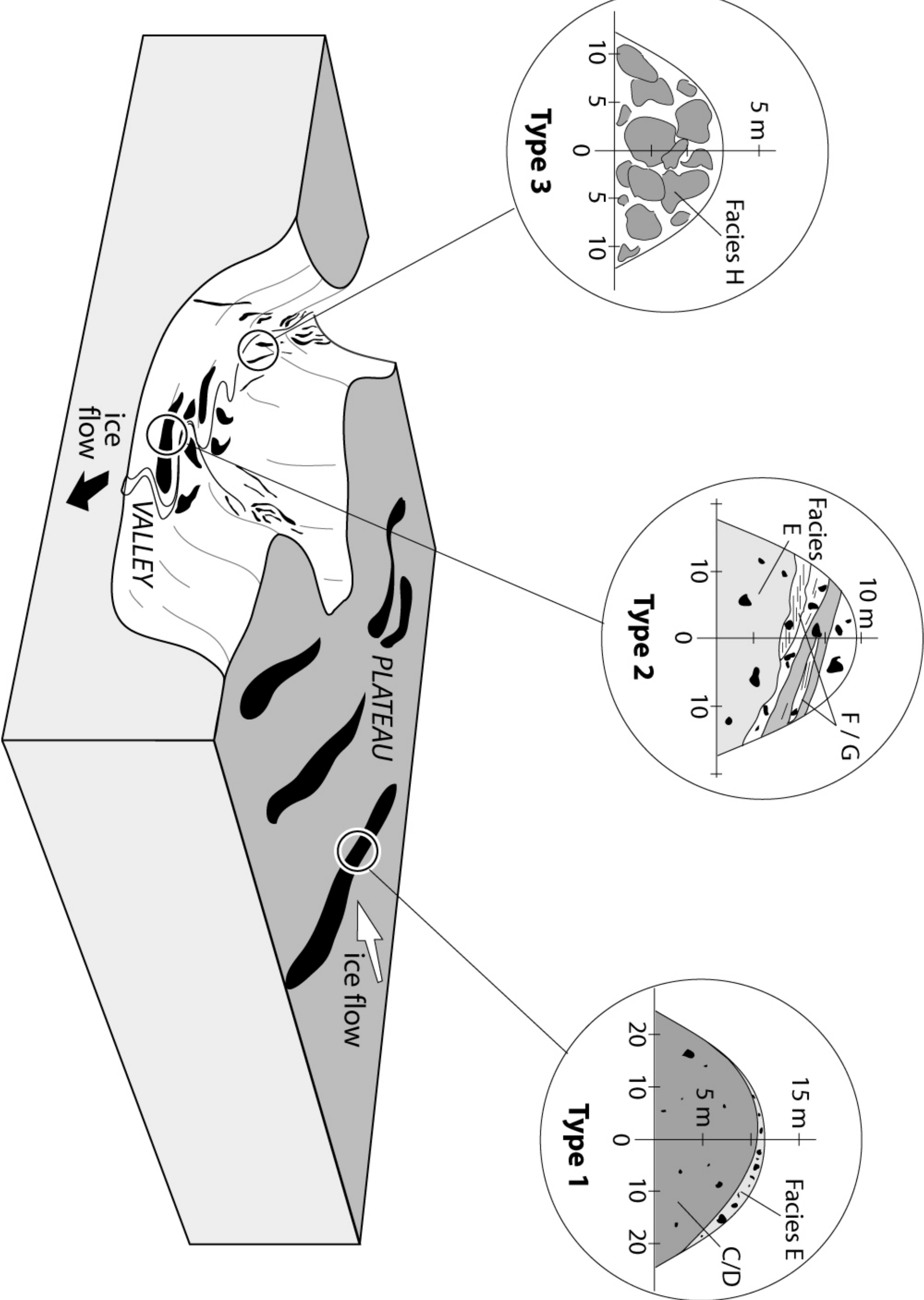



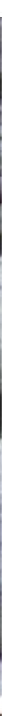

\section{is}
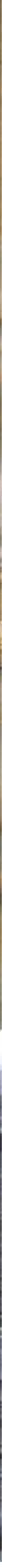
Firm, silty grey till (Facies C)
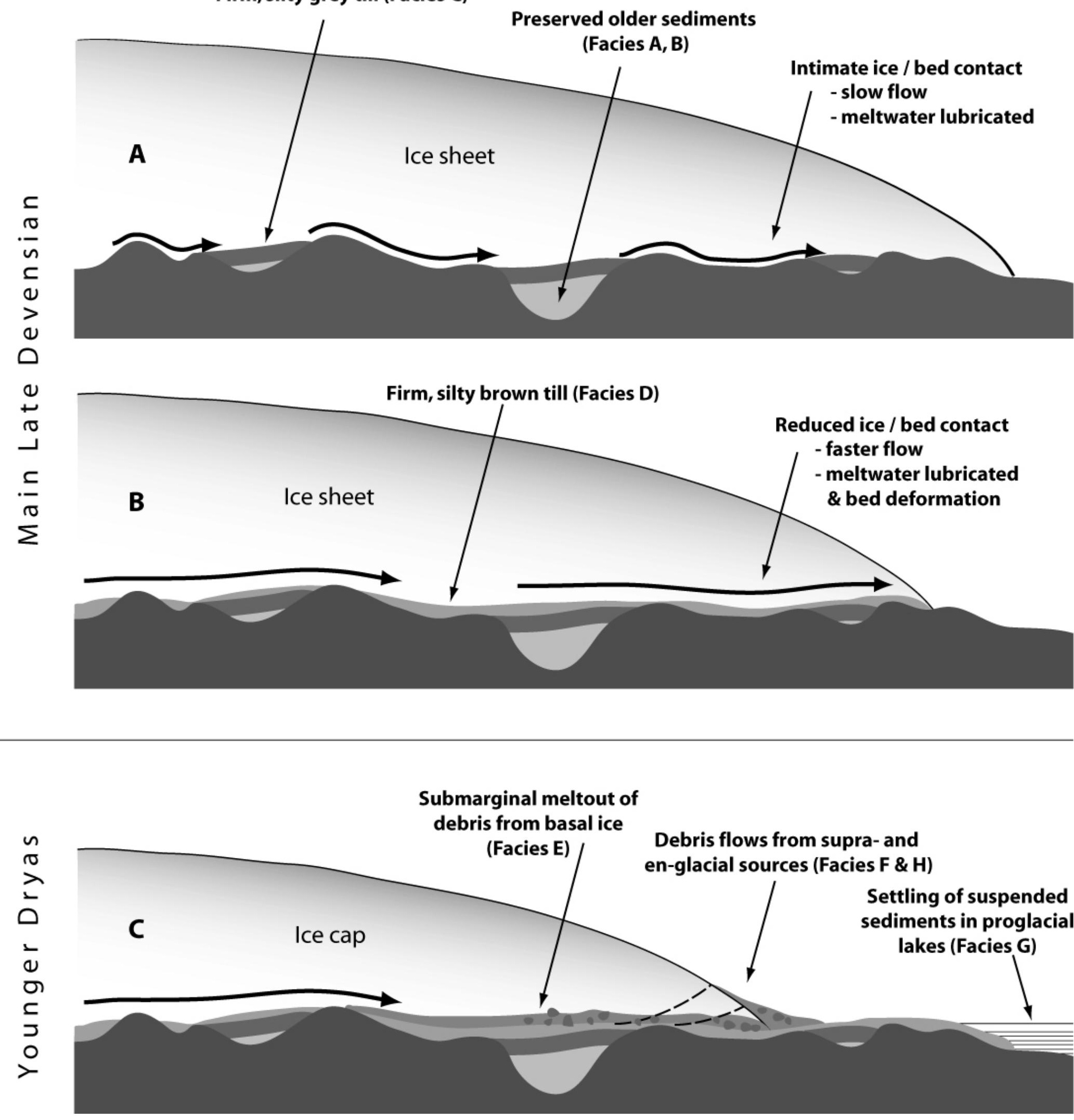